\title{
Generic intertextuality in online social activism: the case of the It Gets Better project
}

Article

Accepted Version

Jones, R. H. (2015) Generic intertextuality in online social activism: the case of the It Gets Better project. Language in Society, 44 (3). pp. 317-339. ISSN 0047-4045 doi: https://doi.org/10.1017/S0047404515000214 Available at https://centaur.reading.ac.uk/47471/

It is advisable to refer to the publisher's version if you intend to cite from the work. See Guidance on citing.

To link to this article DOI: http://dx.doi.org/10.1017/S0047404515000214

Publisher: Cambridge University Press

All outputs in CentAUR are protected by Intellectual Property Rights law, including copyright law. Copyright and IPR is retained by the creators or other copyright holders. Terms and conditions for use of this material are defined in the End User Agreement.

www.reading.ac.uk/centaur

\section{CentAUR}


Central Archive at the University of Reading

Reading's research outputs online 


\title{
Generic intertextuality in online social activism:
}

The case of the It Gets Better project

\author{
Rodney H. Jones \\ City University of Hong Kong \\ Department of English, 8/F Run Run Shaw Creative Media Centre, Kowloon Tong, \\ Hong Kong \\ enrodney@cityu.edu.hk
}

\begin{abstract}
The It Gets Better project has been held up as a model of successful social media activism. This paper explores how narrators of It Gets Better videos make use of generic intertextuality, strategically combining the canonical narrative genres of the exemplum, the testimony, and the confession in a way that allows them to claim 'textual authority' and to make available multiple moral positions for themselves and their listeners. This strategy is further facilitated by the ambiguous participation frameworks associated with digital media, which make it possible for storytellers to tell different kinds of stories to different kinds of listeners at the same time, to simultaneously comfort the victims of anti-gay violence confront its perpetrators, and elicit sympathy from 'onlookers'. This analysis highlights the potential of new practices of online storytelling for social activism and challenges notions that new media are contributing to the demise of common narrative traditions.
\end{abstract}

Keywords: activism, digital media, genre, LGBT discourse, narrative, positioning 


\section{Introduction}

The It Gets Better project was initiated in September of 2010 by prominent sex columnist Dan Savage in response to the highly publicized suicide of Billy Lucas, a 15-year-old boy who hung himself after suffering anti-gay bullying. Savage and his husband, Terry White, posted a video on YouTube relating their own experiences of being bullied when they were young and urging other adults to reach out to 'at risk' LGBT teens with their own stories in order to send the message that 'it gets better'. Over two hundred videos were uploaded in the first weeks of the campaign, and three years later over 50,000 had been contributed. In 2011 around 100 of these stories were transcribed and compiled into the It Gets Better book (Savage and Miller 2011), which appeared on the New York Times bestseller list within weeks of its publication.

The success of the It Gets Better campaign has been cited as an example of the way digital social media can transform social activism. As Brabham (2010) notes, 'vernacular video and collaborative online projects like the It Gets Better projecthold enormous potential to intervene in oppressive cultural arrangements and to actively replace those oppressive situations with visions of possibility' (ब 10). Particularly notable when it comes to this campaign was the way it used practices of online storytelling to transform public perceptions of LGBT intergenerational communication, which in the past had often been framed by mythologies of 'homosexual recruitment' (Goltz 2013). In fact, the project represents what might be the first major example in the US of LGBT adults speaking publically to young people on the subject of sexuality without attracting censure from mainstream media, politicians or religious figures. One way digital media helped to make this possible 
was by providing a channel through which LGBT adults could circumvent social and institutional barriers to communication. As Savage himself notes, 'in the era of social media — in a world with YouTube and Twitter and Facebook - I could speak directly to LGBT kids right now. I didn't need permission from parents or an invitation from a school' (Savage \& Miller 2011: 3). The most important contribution of digital media, however, was not just that it provided a new channel through which these stories could be broadcast, but that it made available to members of the LGBT community a new kind of storytelling, one in which they were able to use publically broadcast 'private' stories to simultaneously comfort the victims of anti-gay violence confront its perpetrators, and elicit sympathy from 'onlookers'.

\section{Narrative and social change}

Narrative has long been recognized as an important tool for the development and regulation of individual and collective identities. Shared stories and shared methods of telling them create coherence within social groups and shared commitment to common goals, values and beliefs (Johnstone 1990, Polanyi 1985). Because of this, narrative has always played an important political role in societies, used both by dominant groups to maintain their dominance, and by marginalized groups to contest it. Mumby (1987: 114) goes so far as to define narrative as 'a politically motivated production of a certain way of perceiving the world which privileges certain interests over others.' The identity stories of members of historically 'defiled' groups are especially shaped by politics, and also play an important role in shaping the politics of those groups. As Walters (2014: 27), puts it, 'for minority groups ... narratives are constructed as lifelines to each other and as insinuation into the larger stories of national identity and personal triumph.' 
A common thread running through much of the work on narrative and social identity has been the acknowledgement that narratives almost never belong to individuals alone, that even when recounting the most intimate details of their personal experience, people draw on common discursive formats which favor the articulation of certain kinds of experiences over others. As Mills (1959) observed long ago, individuals' narratives about their troubles are as much works of history, narratives of societies and social spaces, as they are narratives of 'personal troubles'. Telling a personal story is always a political act, since it always involves a process of negotiation between the individual's understanding of his or her experience and the system of values, beliefs, and social relationships embodied in the narrative genres that his or her society makes available for articulating those experiences. Bamberg (2007: 3) describes these genres as 'pre-existing meaningful templates that carry social, cultural, and communal currency for the process of identity formation.'

The conventionalized narrative genres of a society or of a social group reveal the kinds of identities and experiences that that society or group takes to be legitimate, valuable, and real (Polanyi 1985). At the same time, conventional narrative genres can have the effect of 'silencing' stories of less conventional experiences, including stories of sexual abuse or rape (Fivush 2004), of discrimination against ethnic minorities (Michaels 1991), and of lesbian, gay, bisexual and transgendered experiences (Cohler \& Hammack 2006). Questions about the 'availability of some narratives and the erasure or suppression of others,' says Shuman (2007: 177), are central to an individual or group's ability to claim 'entitlement', the right to speak and be heard, and 'empathy', the right to have their experiences 'recognized' by others. 
Despite the constraints imposed by mainstream narrative genres, marginalized groups are nevertheless sometimes able to creatively appropriate and adapt these genres to accommodate their experiences, thereby altering the dynamics of power within a situation, or even within a society. Indeed, the most effective strategies for resisting the constraints of canonical narrative genres often involve appropriating and adapting them rather than contesting them. Scholars have shown, for example, how women in diverse cultural contexts have used narrative to strategically contest gender boundaries through the strategic mixing of genres traditionally reserved for men with those traditionally associated with women (see for example Kapchan 1996, SchelyNewman 1999, Shuman 1993). Similar observations have been made about the discursive practices of gays and lesbians. Scholars of law, for instance, have described how LGBT activists have appropriated conventional narratives of family life as potent rhetorical tools in court cases and public debates about same sex marriage and adoption (Copeland 2012, Lin 1999), and in my own study of the emergence of the LGBT community in China in the late 1990s (Jones 2007), I show how Chinese gays and lesbians creatively appropriated conventional moral stories and historical tales to create hybrid genres through which their experiences could be represented as legitimate.

What these examples point to is the fact that canonical narrative genres are not rigid or static, but susceptible to 'bending' and 'blending' (Bhatia 1993), and that this flexibility opens up all sorts of possibilities for social change. Briggs and Bauman (1992) refer to this phenomenon as 'generic intertextuality'. Drawing on the work of Bakhtin (1986), which challenged 'the notion that genres are static, stylistically 
homogeneous, and nonoverlapping units,' (Briggs and Bauman 1992: 145), they argue that by appropriating and combining elements of canonical genres, people in less powerful positions in societies can find creative ways to claim 'textual authority' by linking their experiences with traditional storylines, while at the same time also opening up space for revising these storylines.

This paper argues that a large part of the success of the It Gets Better campaign is a result of participants' strategic exercise of 'generic intertextuality', specifically, their appropriation and mixing of three canonical narrative genres -the exemplum (a didactic story meant to illustrate a moral point), the testimony (a story whose main purpose is to bear witness to atrocities of the past and seek redress), and the confession (a story of personal revelation which, through being told, frees its teller of some psychological or spiritual burden). By mixing these three genres, storytellers are able, to claim 'textual authority' and to construct new kinds of identities for themselves and their listeners. I will further argue that the effectiveness of this particular reconfiguration of genres is crucially dependent on the new kinds of participation structures (Goffman 1981) made possible by digital media, participation structures in which the lines between the public and the private, between the narrator and the audience, and between the 'heard' and the 'overheard' are blurred.

The analysis is based on 204 It Gets Better narratives, 104 constituting those reprinted in the It Gets Better book and 100 chosen from the It Gets Better website by selecting every 20 th video from the 2560 that were archived there at the time the research was conducted. In illustrating how these canonical genres are strategically invoked and interwoven, I will focus on two central questions with implications beyond these 
particular narratives. The first has to do with why generic intertextuality serves as such an effective tool for challenging hegemonic power relationships - what are the discursive mechanisms through which this strategy operates? The second has to do with the effect of the media through which stories are told on narrators' ability to bend and blend genres in strategic ways. Our ability to answer these two questions, of course, depends crucially on how we define narrative genres in the first place, and how we conceptualize their role in organizing and regulating social interactions and social identities.

\section{Approaches to narrative genre}

The problem of narrative genre has been taken up by a range of different disciplines including folklore studies, literary theory, linguistic anthropology, and sociolinguistics, each of these disciplines offering a number of competing definitions of genre. Most of these definitions can be divided into either structuralist approaches, which focus on the content, style, and structure of texts, and interactionalist approaches, which focus on how texts contribute to the organization of social occasions and social relationships.

Literary approaches to genre have been heavily influenced by Aristotle, who was perhaps the first major thinker to classify literary works into types based on textual criteria such as topic, medium, effect and structure, an approach which has persisted until the present day (Dubrow 1982). Perhaps the most extreme version of this formalist view of literary genres was advocated by structuralists of the early $20^{\text {th }}$ century such as Gérard Genette (1992), who asserted that the true study of literature should concern not individual texts, by architexts - the genres of which individual 
texts are merely expressions. Structuralist perspectives on genre can also be found in early folklore studies and anthropological approaches to narrative, perhaps best exemplified by Propp's (1968) morphology of Russian folktales, as well as many linguistic approaches, such as Rumelhart's (1975)'story grammars' and Longacre's (1968) tagmemic approach to narrative, and even in the work of systemic functional linguists, who, despite their 'functional' orientation, tend to describe narrative genres in terms of their schematic structures (Eggins and Slade 2005, Martin and Plum 1997).

In sociolinguistics the most influential model of the structure of narrative has been that proposed by Labov and Waletzky (1967), who, based on their analysis of oral narratives of personal experience, observe that narratives generally follow a six part sequential structure consisting of: 1. an Abstract (which introduces the reason for telling the story); 2. an Orientation (which introduces the setting and characters); 3. a Complicating Action or actions (which introduces the 'problem' in the story); 4. a Resolution (which shows how the 'problem' was resolved); 5. an Evaluation (which explains the significance of what happened); and 6. a Coda (which sums up and closes the story). Most of the narratives featured in It Gets Better videos, in fact, follow this structure, consisting of an abstract (in which the narrator introduces him or herself and the reason for telling the story: to illustrate that 'it gets better'), an orientation (in which the narrator explains the circumstances of his or her childhood), a series of complications (in which the narrator relates episodes of physical and/or verbal abuse, feelings of isolation, and often one or several attempts at suicide), followed by a resolution (usually involving moving away and becoming part of a more supportive community), an evaluation (in which the story is interpreted as proof 
that 'it gets better'), and a coda (in which the slogan 'it gets better' is once again repeated).

Later scholars have attempted to apply this general template to the description of more specific narrative genres. Systemic functional linguists such as Eggins and Slade (2005) and Martin and Plum (1997), for example, have shown how different types of oral storytelling follow slightly different schematic patterns. For instance, rather than exactly reproducing the Abstract - Orientation - Complication -- Resolution Evaluation - Coda structure of conventional narratives, anecdotes (defined as reports of remarkable events) are seen to have an (Abstract) - (Orientation) - Remarkable event - Reaction - (Coda) structure (with the Abstract, Orientation and Coda as optional components), and recounts (defined as 'bare' records of events) are seen to have an (Abstract) - (Orientation $)$ - Record of events-(Reorientation $)-($ Coda $)$ structure. Both Eggins and Slade (2005) and Martin and Plum (1997) also deal with exempla, a genre I will argue is invoked in many It Gets Better narratives, and which they define as 'a story that illustrates the validity of shared social values' (Eggins and Slade 2005) and follows the structure: (Abstract) -- (Orientation) - IncidentInterpretation - (Coda). Such schematics, however, have limited utility in helping us to understand how people actually use these genres strategically: while it would not be hard to demonstrate that It Gets Better narratives follow the structure of exempla and contain a host of other textual features such as the frequent use of evaluative clauses also associated with this genre (see below), this does not explain how these textual choices function to transform the relationships between tellers and listeners, particularly in terms of power and social legitimacy. It might also obscure the fact that these stories are more than just exempla, that they draw upon other narrative genres as 
well (including, incidentally, anecdotes and recounts). In order to address these issues, we need to turn to more interactionally oriented perspectives on narrative, perspectives that see narratives not as static textual forms but as discursive tools people draw upon to perform social actions and to claim and impute social identities.

More recent conceptualizations of genre in nearly all of the disciplines mentioned above have moved beyond narrow concerns with structures and taxonomies to embrace more dialogic, interactionalist approaches. In literary theory, for example, post-structuralist critics such as Derrida (1980) have questioned the notion that genres have strict structures and clear boundaries between them, claiming the genre mixing is the rule rather than the exception, and reader-oriented theorists such as Jauss (1974) have considered genres in terms of the socially conditioned relationships they construct between readers and writers.

In anthropology, scholars of folktales and oral narratives have become more interested in the performative aspects of narrative genres, seeing stories not so much as texts as as social occasions in which participants do not just recount events, but also perform particular social practices and enact particular social identities based on shared understandings of how, when, where and to whom different types of stories are most appropriately told, what sorts of people are entitled to tell them, and what sorts of people are entitled to hear them (Bauman 1986, Peterson and Langellier 2007, Shuman 1986). Performance-centered approaches to narrative genres focus less on schematic structures and linguistic features, and more on 'orienting frameworks, interpretive procedures and sets of expectations that are not part of discourse structure but of the ways actors relate to and use language' (Hanks 1987: 670). 
A key aspect of performance-centered approaches to narrative genres is the concept of intertextuality. Influenced by the work of Bakhtin $(1981,1986)$, scholars working in this paradigm point out that any performance must necessarily invoke multiple previous performances, that performances are invariably 'multilayered constructs' (Hanks 1989) in which multiple genres and multiple events are invoked or recalled. The intertextual relations between different genres and events, says Briggs and Bauman (1992: 147) can play an important role in 'ordering discourse in historical and social terms' and making certain kinds of social, ideological, political and economic relationships possible. Because of this, as Schely-Newman (1999: 51) points out, the invocation and mixing of different kinds of genres 'may be a point of contention and challenge, an arena for discursive reconstruction of identity, open to innovation, manipulation and change.'

Finally, interactional sociolinguists, influenced by the work of Goffman $(1974,1981)$, have focused more on the way people use narratives to display social identities and 'align' themselves with their listeners (see for example Bamberg 1997; Schiffrin 1997). Like the performance-centered approach to narrative genre described above, scholars of this approach focus on how telling different types of stories works to construct different types of social occasions. Rather than the fixed schema posited by Labov and Waletzky (1967), genres are more like 'frames' (Goffman 1974, Tannen 1993), which participants take up in interaction in order signal certain kinds of activities and certain kinds of relationships with their interlocutors. 
One influential strand in this approach draws on 'positioning theory', as articulated by Harré and his colleagues (van Langenhove and Harré 1999), to analyze the way narratives are used to negotiate (and sometimes contest) the positions tellers and listeners can assume within the 'storyline' of the social occasion, as well as within broader 'storylines' which reflect the 'moral orders' of the societies in which they live (see for example Bamberg 1997, Wortham 2000). From this perspective, certain genres can be seen as making different kinds of positions available to tellers and listeners. 'Complaint stories', for example, position tellers as victims and listeners as commiseraters (Günther 2005), and what Dingwall (1977) calls 'atrocity stories' position tellers as heroes and listeners as witnesses. Kraus (2007) points out that such acts of self and other positioning in storytelling are central to the negotiation of power and 'belonging'. At the same time, positioning is a dynamic and strategic process, and participants can creatively construct and alter narratives to make available multiple or ambiguous positions for themselves and their listeners, or to challenge the positions made available to them by particular genres.

Even more fundamental than the 'moral' positions tellers and listeners of stories negotiate are the very concrete, situated positions of 'tellership' and 'listenership' that they take up in interactions, positions Goffman (1981) talks of in terms of 'participation frameworks'. The idea that the telling of stories just involves two kinds of participants, tellers and listeners, is a gross oversimplification: storytelling can involve a whole range of participants including addressees, unaddressed but ratified participants (bystanders), and unaddressed and unratified participants (eavesdroppers). Building on Goffman's notion of participant frameworks, Bell (1984) argues that speakers carefully construct their utterances (in terms of content 
and style) with different sorts of audiences in mind, sometimes playing to multiple audiences at the same time. One example of the way storytellers can strategically play with the different (sometimes ambiguous) participation statuses of their listeners can be seen in Fung's (1999) description of the way Chinese parents tell stories about their children's bad behavior to other adults in the children's presence as a way of socializing them into the moral standards of the community. In this case the children occupy multiple participation statuses (as both overhearers and addressees), as well as multiple moral positions (as both judges and perpetrators).

From this perspective, different genres do not just represent different structural arrangements of linguistic features; they represent different kinds of relationships between storytellers and their audiences, and different ways they are called upon to be accountable to one another. What is strategic, then, about the mixing of genres, is that it provides opportunities for storytellers to form new kinds of relationships with their listeners through manipulating the 'moral positions' and participation statuses they make available to them.

This is not to say that in this perspective the kinds of structural features pointed out by Labov and Waletzky and others are irrelevant. Rather than being seen as evidence of strict schematic structures, however, things like styles, motifs, the ordering of elements, and the use and placement of features like evaluative clauses are see as ways storytellers 'invoke’ (Briggs and Bauman 1992) or 'key’ (Goffman 1974) different generic frames and invite listeners to take up certain roles in the storytelling event. As Bamberg (1997: 341) puts it, interactional approaches to narrative do not ignore its structural organization, but instead constitute 'an attempt to unite the 
pragmatics of narrating with the linguistic (structural) analysis a la L[abov] and $\mathrm{W}$ [aletzky] into one that emphasizes more strongly issues such as the assignment of praise and blame.'

\section{Narrative 2.0}

One area where these more interactionally oriented approaches to narrative genre are particularly relevant is in understanding the new forms of storytelling made possible by digital media. The ways storytellers are able to manage 'tellership' and 'listenership', and even their ability to make available different sets of moral positions for themselves and listeners, depends crucially on the material contexts in which they tell their stories, including the technological modes through which these stories are transmitted (Peterson and Langellier 2007). Digital media have given rise to a host of new narrative forms and practices from the 'small stories' (Page 2010) people share on Facebook and Twitter to the videos they upload to YouTube. What characterizes such stories, says Alexander and Levine, (2008: 40), is that they tend to be 'openended, branching, hyperlinked, cross-media, participatory, exploratory, and unpredictable.'

Because of these characteristics, digital stories can be particularly useful for the kind of online social activism seen in the It Gets Better campaign. First, they create new channels and contexts for communication, putting into the hands of heretoforemarginalized individuals the ability to produce sophisticated multimodal messages and broadcast them to large numbers of people. Second, because of the participatory nature of the medium, audiences can talk back to storytellers, help to spread their stories quickly though digital networks, build on the stories others have told, and 
contribute stories of their own, facilitating both the dissemination of messages and the exercise of 'collective coping' (Lindgren 2012).

Among the chief affordances of digital storytelling for social activists are the new opportunities they provide for storytellers to creatively construct multiple positions for their audiences through mixing and 'mashing' different genres and exploiting the ambiguous participation frameworks of networked communication. Partly because digital tools make it much easier to mix (and 'remix') different semiotic elements, and partly because practices of digital storytelling are so new that they are not yet subject to the kinds of generic constraints associated with other types of storytelling, digital storytellers are often much freer to recombine 'both material resources - content, and immaterial resources - genre conventions ... in novel ways' (Burgess 2006: 6). Fagerjord (2003), for example, has shown how remixing narrative genres has become a widespread creative practice on YouTube, a practice she refers to as 'rhetorical convergence'.

At the same time, the ambiguous nature of digital stories on social media sites as both private communications, aimed at particular individuals, and as public performances, broadcast to a wider audience, give to storytellers new opportunities to creatively exploit the ambiguous participation statuses of their audiences. Media critics have noted how communication over social networking sites often results in what they call 'context collapse': the difficulty for communicators to control the contexts in which their messages will be read due to the fact that they are simultaneously broadcast to different audiences. Scholars who have studied the actual practices of people on these sites, however, have noted the sophisticated strategies they develop for discursively 
constructing different kinds of participant roles for various audiences, and even for turning the ambiguous participation statues of their audiences to their advantage. Frobenius (2014) for example, discusses how producers of YouTube videos make use of a range of linguistic cues to 'design' different participation roles for their audiences, and boyd (2014) describes how adolescents engage in practices like 'subtweeting', conducting private conversations on the public platform of Twitter in language carefully designed to create different positions of inclusion and exclusion for potential readers.

In my analysis below I will argue that part of the success of the It Gets Better Project lies in similar practices of exploiting the ways digital technologies facilitate the mixing of different genres the construction of multiple participation roles for viewers, allowing narrators of It Gets Better stories to simultaneously tell different kinds of stories to different kinds of listeners at the same time. Much has been made of how the campaign has opened up a channel of 'direct communication' between LGBT adults and youth. Just as important, I will show, are the channels of 'indirect communication' that it has made possible, forms of communication in which members of the public who are not directly addressed are nevertheless invited to 'overhear' the stories and to reflect upon and be accountable for their part in them.

\section{The Exemplum}

The most obvious narrative genre that It Gets Better videos appropriate is that of the exemplum, a didactic story which serves as an illustration of a moral point. The genre dates back to ancient Greece, but became particularly popular in the Middle Ages in the context of religious sermons (Lyons 2006). The status of the It Gets Better 
narrative as an exemplum has its roots in the very first video produced by Dan Savage and Terry White, who explicitly call on viewers to make videos in order to send the message to suffering LGBT youth that 'it gets better'. In nearly every single contribution to the project, speakers' stories of pain and redemption are framed by this didactic intent.

'It Gets Better videos' typically begin with speakers announcing their intention to produce an exemplum in what Labov and Waletzky would label the 'abstract' of their narratives:

Hi, my name is David from Orange County and I'm making this video so that you know whoever watches that it gets better. (David from Orange county)

Hi my name is Taylor, and I'm just here to make this video to tell you guys that it does get better. (Taylor from Indiana)

Hi guys, I'm Brace, some of you might know me as Posha, and I'm here to tell you that it gets better. (alessiasrequiem)

They also typically end with a coda in which the phrase 'it gets better' is repeated as the 'moral' of the story:

Just remember, no matter what, it does get better (Paola in Venezuala) 
Guys don't be scared because no matter what, like I said, at the end of the day it's gonna get better. (Taylor from Indiana)

In Labov and Waletzky's model, the abstract and the coda are key points in a narrative in which the world of the story and the occasion of its telling interact. The abstract serves the function of introducing what the story is about and why it is told, constituting a kind of 'promise' to the listener that what will follow is relevant to them and how it will be relevant. Codas serve a similar function of 'bridging the gap' (Labov 1972: 365) between the narrated events and the narrative event, often summing up the effect of the events on the narrator and re-emphasizing the relevance of the story to the listener. In many narrative genres, the abstract and the coda are left out, and their inclusion in almost all of the It Gets Better stories I analyzed serves to strongly signal the didactic intent of these stories.

Another common feature of exempla is that they usually include an explicit evaluation section, usually occurring just after the resolution, in which the meaning of the story is explained. In It Gets Better videos this section is often quite lengthy, and often consists of a refashioning of the preceding narrative into a kind of logical argument in which what happened is contrasted with what might (or might not) have happened had the narrator not 'stuck it out'.

none of this would have happened if I were not here. If I had ended my life, I would not have been able to meet so many wonderful people. I would not have experienced the togetherness and belonging that comes from truly deep friendships. I would not have been able to fall in love. I would not have known 
what it feels like to be embraced by a community. I would not have been able to see that life does get better. (Juan Carlos Galan)

Another salient feature of these evaluation sections is that they also frequently end with the narrator offering the listener advice. In other words, a key function of evaluation in these narratives is to invite the listener to apply the lesson from the narrator's story to his or her own life:

Don't take your own life. It's not worth it. If you take your own life, they win. And if you take your own life, that's one less gay person of color, or white, or disabled, or multi-abled, or whatever, that isn't here, able to show them the truth. So please love yourself. Please be strong. And you'll be all right. That I do promise you. (Gabrielle Rivera)

The abstract, coda and evaluation sections, however, are not the only places in which evaluation occurs. Another feature that marks these stories as exempla is the frequent intrusion of evaluative clauses into other sections of the narrative. As Martin and Plum (1997) observe, since the purpose of exempla is to share a judgment about an incident, the action is often regarded as subordinate to the message, giving narrators license to frequently suspend the action to offer evaluative statements.

I just didn't believe it would ever get better. I didn't think it was possible. I tried to kill myself when I was ten years old. And again when I was twelve. And again when I was thirteen. (Laurel Slongwhite) 
I tried to kill myself. I was in intensive care for three days. I was twenty-two years old. But here's the thing: Just six months later, things started to get better. (Barbara Gaines)

The continual punctuation of these narratives with evaluative statements, usually containing some permutation of the phase 'it gets better' is reminiscent of the repetitive language found in much ritualistic storytelling, hearkening back to the roots of exempla in religious sermons.

Through this frequent use of evaluation, narrators of It Get's Better stories create a specific kind of relationship with their viewers, explicitly claiming the right not just to tell their stories, but also to interpret the meaning of these stories for their audience. Claiming the right to produce an exemplum involves claiming a broader social identity, that of a 'teacher' or 'mentor', and of positioning listeners in the role of 'students' or 'disciples'. In this regard, producing an exemplum can be seen as 'a bid for a kind of power' in which 'narrators assert their authority... to take up the role of knower' (Toolan 1988: 3).

To be effective, however, exempla must also create identification between tellers and listeners (Martin and Plum 1997). Exempla depend for their effectiveness on a belief in 'the predictable repetition of precedent' (Lyons 2006), the belief on the part of listeners that what happened in the story could happen to them. Alessiasrequiem, a 22 year old college student emphasizes this in her video when she insists that her story is not about her: 
It's about you. You who's still in the closet, who's living with homophobic parents, who's getting bullied, who goes home every night and struggles with issues of self worth, you who are afraid. I came out to show you that it can be done, to show you that you don't have to keep living a lie, to show you that even if things seem hopeless, even if you feel everyone's against you, that you're not alone, that it doesn't matter because you can come out on the other end of it stronger. I'm living proof that it gets better. (alessiasrequiem)

Exempla make speakers accountable for producing narratives that hearers can, to some degree, recognize and relate to, narratives which have the potential to acquire a larger significance beyond the particular experiences of the individual teller. As David in Orange County observes in his It Gets Better video, 'it may not be the exact same situation, the stories are all different, but the meanings are the same.'

Narrators encourage this sense of identification in a number of ways. The first has to do with their use of the medium of digital video. With the exception of the professionally produced videos posted by celebrities and organizations, nearly all of the videos consist simply of speakers sitting in a room, looking directly at the camera and addressing the viewer. Although there is nothing particularly sophisticated about this technique, it proves particularly powerful in creating solidarity between the speaker and the viewer. The gaze of the speaker directed outward creates an emotional connection and positions the viewer not just as a member of an 'audience' but as an interlocutor. Furthermore, the lack of technical sophistication in these stagings helps to mark the videos as 'authentic', made by people 'just like you and me'. 
Another way speakers in It Gets Better videos encourage identification is by explicitly positioning themselves as future versions of their viewers, and inviting their viewers to contemplate the time when they will take on the role of speakers, offering up their own experiences as exempla. It is quite common, for example, for speakers to conjure up their 'past selves' and speak to them in the same way they are speaking to their viewers:

If I could now, at twenty-six, speak to my fourteen-year-old self-or even my nineteen-year-old self in college-I would say don't worry about being gay. That's who you are. That's how God created you. He created me as a Jew, and he created me as a gay person. (Justin Spiro)

It is too late for me to speak to my own sixteen-year-old self, so instead I want all of the misfits and weirdos and artists and queer kids to know a couple of things I wish someone had told me back then. (Ivan Coyote)

At the same time, speakers also frequently invite listeners to imagine themselves as LGBT adults with the responsibility to give advice to LGBT youth or to fight for LGBT equality:

MARK: So if you're thinking as a teenager that maybe hurting yourself is going to be a good way of getting out of the pain, don't do it. Just think of yourself being a little older, maybe not 40 , maybe 25 . But think of yourself 
coming back and telling you that it's going to be okay, because it is. (Google Employees)

Through this process of 'trading places', tellers and listeners become accountable to each other as members of a kind of 'oral tradition'. And many viewers actually make good on this commitment by going on to make It Gets Better videos of their own. In fact, many of the videos by younger contributors relate how they were inspired by watching the It Gets Better videos of adults.

Hello, my name is Jacob and I'm here to thank the It Gets Better project for all their love and support in helping me my time of need. I know that it can be very hard growing up, you know, different and I would like to let any gay transgender lesbian or bisexual or anyone who's ever been bullied, to let you guys know that it does get better. (Jaykounter)

The exempla in It Gets Better videos, then, are not just exempla about how to live one's life, but how to turn one's life into a story and pass it on to others. The way the genre encourages this process of the collective 'storying' of the self explains in part why the campaign spread at the rate it did over social media. The effect of this positioning of the audience as potential storytellers helps to facilitate the formation of an audience that converges around a common narrative tradition.

However, this is not the only kind of audience these exempla construct. As mentioned above, the ability of the It Gets Better project to make this kind of relationship between LGBT adults and teenagers publically available constituted a dramatic shift 
in the way LGBT intergenerational discourse had been perceived, at least in the US, and one of the key strategies through which this is accomplished is through the appropriation of the socially sanctioned genre of the exemplum. The effectiveness of this strategy, however, depends not just on these exempla being heard by 'at risk' teens, but on them being overheard by non-LGBT adults, especially parents, teachers and school administers.

In indirectly addressing this audience, narrators use the same combination of didacticism and identification. First, they claim the authority to 'teach' members of this audience about how to give advice to 'at risk' teens by both offering stories of their childhood experiences with unresponsive adults as examples of how not to do it, and by demonstrating through their own storytelling practices more appropriate forms of mentoring.

I would get sent to the principal's office with these kids that were obviously torturing me... and be told this was happening because I wasn't keeping my private life private. (Jakes Shears)

MICHAEL: I grew up at the dinner table, hearing conversations about how gay people should die of AIDS, how gay people were less than, you know, straight people. And it really caused me to not feel very safe at home. And at the same time, I didn't feel very safe at school either. (Google employees)

In the telling of such stories, unsupportive adults who might be overhearing them are positioned not unlike the Chinese children in Fung's (1999) work, forced to listen to 
stories of their bad behavior told to others, in this case to the very victims of their unsupportiveness.

At the same time, the narrators also seek to create identification between themselves and non-LGBT adults, also primarily by talking about them -- but in this case portraying them as 'fellow adults' with common values and goals whom teenagers should approach for help.

If you are being bullied, say something. Supportive adults can be your allies. (Juan Carlos Galan)

If you're dealing with violence, report that to the police, to your parents, to the school. (Tuan N'Gai)

But more importantly, narrators create identification with non-LGBT adults by talking to young people in a way that is recognizable to most parents and teachers, including using the familiar genre of the exemplum. Just as narrators position young viewers as part of a narrative tradition of mutual support within the LGBT community, they position non-LGBT adults as belonging to a narrative tradition of 'supportive adults', and encourage them to draw on this tradition in their own future encounters with LGBT youth. And just as LGBT youth have responded by contributing their own videos, non-LGBT adults, including celebrities and politicians, have also done so. 
I add my voice to the chorus of parents, friends, teachers, mentors and teachers in your neighborhood and across the country to say: It gets better. (Nancy Peolosi)

\section{The Testimony}

The second canonical genre evident in It Gets Better videos is the genre of the testimony. The testimony is a mode of storytelling in which a witness recounts some sort of crime or transgression for the purpose of indicting its perpetrators. The function of testimony is to bring some action, experience or phenomenon into 'the light of day' so that those involved can be held accountable. Since the end of World War II, when Holocaust survivors were asked to testify as witnesses to war crimes, testimony has been a prominent rhetorical device in human rights discourse (McLagan 2006). Over time, conventions for the performance of testimonial narratives have developed, which typically include the inclusion of episodes of abuse and suffering designed to elicit empathy from the audience. Such episodes of abuse take a central place in It Gets Better videos:

So I started telling other kids that I was gay, launching what was probably the worst year of my life. I was harassed; I was followed; I was threatened; kids wanted to kill me. I couldn't go from class to class without being accosted. Kids would throw desks and chairs at me in class and the teachers would just pretend that they didn't see what was going on. (Jake Shears)

Because I was not masculine, the kids in school made fun of me constantly. They would write profanities about me in the bathrooms, taunt me during PE 
class, and call my house and say nasty things to me on the phone. I remember walking into a classroom and having all the students yell offensive and derogatory things at me while the teacher did nothing about it. The school staff just let the bullying happen. They believed that I was asking to be bullied by being different from everyone else.

(Juan Carlos Galan)

The important thing about such testimonials is that they are not just designed to elicit empathy, but are also claims that the victims of these abuses are deserving of empathy, that their suffering is legitimate and worthy of the genre of the testimony. Empathy, as Shuman (2007: 180) reminds us, requires a kind of 'allegorization' or 'transvaluation' of the storyteller's experiences which connects it to larger narratives of human suffering.

So central are such tales of suffering to these videos that when tellers do not include them in their stories, they must somehow account for their exclusion and offer up some other credentials for being able to offer a testimony:

I wasn't bullied...but I was deeply in the closet. I was always aware that the wrong gesture, look or tone of voice could grab the attention of someone who might want to hurt me. (Michael Wells)

I don't know what it's like to be picked on for being gay. But I do know what it's like to grow up feeling that sometimes you don't belong. (Barack Obama) 
One way testimonies differ from exempla is that external evaluations are far less frequent. Consistent with expectations that testimony is meant to constitute an objective recount of events without embellishment, most of the narrative clauses depicting abuse are not followed by evaluative clauses. They are left to 'speak for themselves'.

Another common feature of testimony is that the suffering results not just from the abuse but also from a long-standing inability of victims to have the abuse recognized and to gain redress. In this regard, narrators take on the role of surrogates, voicing out both the suffering of their own past selves and the suffering of their viewers.

Testimony, especially in human rights discourse, is rarely done solely for the benefit of the individual. The task of a witness is to bear witness on behalf of a wronged group or class of people.

[T] he teacher did nothing about it. The school staff just let the bullying happen. (Juan Carlos Galan)

[A]11 the adults who were there to protect me didn't protect me. Nobody stepped in. (Michael Arnold)

The final ingredient of the testimony is the naming the perpetrator(s) of the suffering and holding that person or group up for public judgment. The perpetrators of abuse in It Gets Better videos, however, are rarely identified by name. More often they are broad categories of people: 'bullies', 'kids at school', 'cruel people', 'parents', 'teachers', 'ministers', and 'psychiatrists'. This absence of specific naming, however, 
does not make the 'shaming' less potent. In fact, in some respects it makes it more powerful, opening up a wide enough rhetorical space for almost any non-LGBT adult to perceive themselves as perpetrators, if not for causing the suffering directly, at least for 'letting it happen'. It makes the perpetration of suffering of LGBT youth a pervasive feature of society as a whole. As one speaker puts it:

Bullying isn't just what real people in real time say to you or try to do to you. Bullying is everywhere - it's in the words of fearful, judgmental parents who are trying to control you. (BTW: it's also in the words of well-meaning but misguided parents who are trying to "protect you from being hurt.") Bullying is in the news and in government policy. It's in the imagery of pop culture. It's in religion. And as a result, it gets into your head. (Cameron Tuttle)

These various functions of testimony-- offering evidence, bearing witness, and shaming - highlight the fact that like exempla, testimonies have the potential to construct multiple positions for hearers. First, they position hearers as fellow victims, and serve to 'give voice' to the stories they are, for whatever reason, unable to tell. Second they position hearers (and overhearers) as judges, inviting them to acknowledging the injustices that were perpetrated and feel outrage. Finally, testimony addresses the person of the perpetrator who is held up for 'shaming; and called forth to answer for his or her actions.

McLagan (2006) calls testimony an 'intercultural technology', because of its power to bring people together across the boundaries of these three subject positions: judge, witness, and perpetrator. The audience that is created through the genre of testimony 
is simultaneously a 'guilty' audience that has 'allowed this to happen', and a 'righteous audience', an audience whose members are called to hold one another accountable to put an end to the abuse and suffering.

\section{The Confession}

The third important narrative genre invoked in It Gets Better videos is the confession. Like the exemplum and the testimony, the confession is a genre with a long literary tradition. It is a narrative in which the intimate or hidden details of a person's life are revealed. Prominent examples include Augustine's Confessions (400 AD) and Rousseau's Confessions (1782-89). In their narrowest sense, confessions are often associated with the admission of some sort of wrongdoing. In the broader sense in which I am using the term here, however, a confession is a revelation of the innermost self, which results in some sort of redemption or liberation. Augustine's Confessions, for example, functions not just as an admission of guilt for the author's youthful debauchery, but, more importantly, as the documentation of a spiritual journey from confusion to enlightenment, and Rousseau's Confessions is more of an aesthetic homage to truth than an admission of fault. 'My purpose,' he writes, 'is to display to my kind a portrait in every way true to nature, and the man I shall portray will be myself' (Rousseau 1992: 8). Whether on not what is revealed is negative, positive or neural, the essence of confession is disclosure, the bringing of some information from the private sphere to the public sphere (Plummer 1995), and the underlying assumption governing the genre is that secrecy functions as a kind of prison, isolating the individual from society, and that disclosure is fundamentally liberating. 
It Gets Better videos are marked as confessional narratives both in terms of their content (usually involving intimate details of the speaker's life) and in terms of their structure (tracing a movement from secrecy to openness). The form these confessions most often take is the 'coming out story', a form that Plummer (1995) identifies as perhaps the most critical narrative genre for gays and lesbians in contemporary society. 'Coming out stories' are confessions in their truest sense, stories of selfdiscovery in which narrators/characters move from suffering and secrecy to a state of self-acceptance and transcendence.

Although the term 'coming out' was not widely used when Foucault wrote his History of Sexuality (1990, English translation originally published in 1978), the notion of confession is central to his ideas about how people talk about their sexuality, and specifically, to the invention of the 'homosexual person' in modern discourse. Foucault, however, sees confession in a much more negative light, depicting it as a ritual through which those in positions of power - priests, parents, physicians and psychiatrists -- maintain control over others. Rather than a tool for liberation, he sees confession is a technology for disciplining citizens. This perspective is useful insofar as it reminds us that to be positioned as a confessing subject often is a function of one's lower status in society. The fact that gays and lesbians have to 'come out', publically acknowledging their difference, in fact, is itself evidence of their 'isolation from the canonical narrative' (McLean 2008: 1696). At the same time, however, as I will argue below, such acts of disclosure can also serve as strategies for reclaiming a place in the canonical narrative. 
Stories of 'coming out' are important features in almost all of the It Gets Better videos produced by LGBT individuals. In fact, for many narrators, the main source of their suffering is not persecution from others, but the suffering that came from holding the secret of their sexuality inside:

Even though I was popular and friends with lots of different people, I felt alone, really alone, like no one knew the real me. On the outside, I was a thriving, active, make-my-family-proud, successful teenager. But on the inside, I was emotionally numb, comatose, flat-lining. (Cameron Tuttle)

While acts of disclosure in the stories often result in further persecution, being bullied at school or rejected by family members, the overwhelming conclusion about 'coming out' in nearly all of the videos is that it is a positive act, often the very act that makes it possible for things to 'get better'.

It was so refreshing to suddenly have someone to count on. I had been keeping this secret my whole life, and I was finally able to experience what it was like to be completely honest with another person. (Stewart Taylor)

Once you tell society you're gonna do you instead of them it because easier to do it over and over again and to love living life. Being different for grants you a creative license that applies to everything you do. It's like a free pass to say screw the status quo, and its so liberating. (Mason Sheffield) 
While a distinction needs to be made between the act of coming out itself and the 'coming out story' which recounts this act, this distinction in It Gets Better videos is inevitably a blurry one. Liang (1997: 293) defines the act of coming out in terms of its performativity: it is a speech act that not only describes a state of affairs, namely the speaker's gayness, but also brings 'a new gay self, into being'. It can be argued, though, that every retelling of a coming out story is a re-performance of the initial speech act, a point that is particularly relevant to It Gets Better videos, which, because of their publicness, inevitably involve the disclosure of the speaker's sexuality to those to whom it has not yet been disclosed. Several speakers, in fact, make explicit mention of this fact:

I never officially came out anyone else in my family so if they see this, congratulations, now you know! (David from Orange County)

Such 'comings out', like the exempla I discussed above, are directed at multiple audiences. They are often directed towards specific interlocutors, whose relationship with the speaker is seen to hinge on their reaction to the revelation; they are directed towards other friends, family members or acquaintances who experience the revelation more indirectly; and they are directed towards those unrelated to the speaker who are invited to witness first hand a successful act of 'coming out' and how it 'makes things better'.

In fact, for some LGBT youth, It Gets Better videos preform the function of modeling the coming out process, spurring them to proceed with their own 'coming out': 
I accidentally ran into the It Gets Better project and I started watching the videos I just got completely obsessed. I mean, I just could not stop watching and I watched hundreds and hundreds of videos for like a month straight, and finally one night came along and I call up my best friend $\mathrm{KK}$ and I am I am just like in tears and I call her up and I tell her KK I need you to come over and stay the night I need to talk to you about something it's very important. (jaykounter)

'It Get's Better videos' however, also contain confessions of things other than speakers' sexuality. One of the most common revelations in the videos, and one which comes closer to the admission of a 'transgression', is the confession of a suicide attempt:

There was a time in my life where I actually tried ending my life. I swallowed a bunch of pills and ended up in the hospital. I wanted to die because things were so bad. I felt like I didn’t want to live anymore. But afterward, lying in the hospital bed, I realized I had so much to live for. I had so many things that were good in my life. I'm smart. I'm a nice person. I'm a good person. I am a human being, and I want to live. (Chaim Levin)

These revelations are much more in line with more traditional forms of confessional narrative in which speakers express regret for deviating from the 'proper path' and invite hearers to share with them the joy and relief of having found themselves again.

One interesting sub-genre of the It Gets Better video is that in which former bullies confess their past wrongdoings and ask for forgiveness: 
I myself am straight and always have been. I've lived my whole life in South Carolina which is in the Bible belt of the United States so I was kind of programmed to hate or in the very least dislike gays in school for a long time, I'll own up to it, and I am ashamed of it, I used to bash members of the LGBT community and feared that if I didn't I would be called gay myself and bullied even more that I already was. (Gene from South Carolina)

I saw the program It Gets Better and I was on the other end of it growing up. I was the bully, one of the bullies. There was like three or four of us, and we were fucking bad. People got beat up, kicked, punched, put the boots to. It was bad growing up. Um...It was a very small-minded town, very small-minded people, If you didn't fit in, if your skin was the wrong color, if you had the wrong hairdo, you got beat up, pretty much that's how is was... I'm sorry. I cried many nights. Even being a bully. It was hard. I don't know why it happened, or what twisted screwed up thoughts were going through my head...I have no excuses.... It's kind of embarrassing.. I just hope you all get through whatever you're going through. That's it. (guyzack327)

Such confessions not only serve as compliments to the testimonies of LGBT victims, they also function to humanize the 'others' of these testimonies. Most importantly, they further highlight the redemptive power of confession itself, a power which can even transform the 'villains' of bullying narratives into legitimate members of the community. In fact, in some respects the confessions of former bullies put these 
speakers in a position in which they are performing their own 'comings out' which also involve a certain degree of risk of rejection or persecution:

I will be posting this video on Facebook as well so my whole friends list knows my standing on the issue of equality for all LGBT community members. Yeah. I may lose a few friends. But if you think about it, if they unfriend me or block me for standing up for equality for people they were never true friends in the first place. (Gene in South Carolina)

Whether the confessing subject is gay or straight, and whether what is being disclosed is a specific transgression or the secrets of one's long hidden desires or identity, the theme that runs through all of the confession narratives in It Gets Better videos is the notion of the 'true self': First, that there exists a 'true self' that is waiting to be revealed, and whose revelation is somehow a prerequisite to becoming a 'healthy', 'happy' human being, and second, that the way to discover and reveal ones 'true self' is through language. The 'true self' is a kind of 'birthright' that people must claim through telling stories.

Finding my true sexuality has changed my life and I wouldn't change anything that I went through for the world. I have found who I really am and I am happy now. And that is all that matters. (Hunter Brady)

It wasn't until college that things began to get clearer, that I began to realize that there was a truer me, within the me that everyone else knew. (Adam Roberts) 
There is nothing greater in life than to be able to be who you are. (Suze Orman)

If you can just learn to love yourself for who you are and be the person you were meant to be, it won't matter how many people are against you. (Stewart Taylor)

It is this notion of the 'true self' to which the genre of the confession in It Gets Better videos holds speakers and hearers accountable. Speakers are held accountable for 'being themselves', and hearers are held accountable for 'accepting' them. The audience constructed by this genre is one built upon the principles of honesty and tolerance in which the strength of the society depends on the right of each individual to enact their 'authentic selves'.

\section{Conclusion}

Despite the outpouring of support for the It Gets Better project, it has not been without its critics, many from within the LGBT community itself. Among the most persistent complaints have to do with the homogeneity and 'conventionality' of It Gets Better narratives, which Tseng (2010: 1) facetiously summarizes thusly: 'high school ends and the bullying stops: you'll move to an urban gay enclave, meet the man of your dreams, and have a wonderful, sparkly, magical life.' This narrative template is criticized not just for its promotion of conventional middle-class values, but also for the fact that it put the onus on the victims of bullying to solve the problem themselves (by escaping from it) rather than directly confronting the perpetrators of antigay violence (Femmephane 2010). This paper has challenged this critique by arguing that it is partly the appropriation of conventional narrative genres and 
traditional themes that enables the participants in the project to claim 'textual authority' and to confront the perpetrators of anti-gay violence in new and creative ways.

At the beginning of this paper I asked how practices of generic intertextuality operate to disrupt power relations among different groups in society. This analysis suggests that one of the main ways it does this is by allowing storytellers to claim a range of 'moral positions', which may not have been traditionally available to them in canonical narrative genres, and also to make available a range of new moral positions for their listeners. By invoking the genres of the exemplum, the testimony and the confession, narrators in It Gets Better videos are able to simultaneously claim the authority of teachers, the righteousness of witnesses, and the intimacy of confidants. What makes these acts of positioning even more effective is the way the participation frameworks of online social media allow narrators to make different kinds of positions available to different kinds of hearers and overhearers, to, in effect, tell different kinds of stories to different kinds of people. When they are broadcast into the bedrooms of suicidal teenagers, they become interventions. When broadcast onto the computer screens of bullies they become indictments. When broadcast to parents, teachers and school administrators, they become appeals for action. And when broadcast to LGBT adults, they become validations of their own experiences. More importantly, however, despite the different moral positions made available to different kinds of people, that campaign positions them all as potential storytellers who, by making their own videos as LGBT adults with similar experiences, as grateful LGBT teens, as supportive non-LGBT teachers, parents and public figures, and even as contrite former bullies, they can contribute to making things better. 
The most important thing about this strategy is that it has increased the campaign's potential to really make things better, not just by preventing individual teenagers from killing themselves, but also by encouraging teachers and parents to change their behavior, by inspiring systemic changes in schools and other institutions, and by shaming politicians into enacting legislation that protects against discrimination and promotes equality.

In a way, this analysis challenges the post-modern assertion that people no longer believe in 'grand narratives' (Lyotard 1979), and especially the notion that digital media like social networking sites are leading people even further away from common storylines and into the thicket of individual, narcissistic 'small stories'. The It Gets Better campaign, on the contrary, operates by weaving together all of the 'small stories' of contributors into a larger 'narrative of emancipation' which is recognizable to both gay and straight, both victim and bully. By making available multiple subject positions from which speakers can tell their stories and listeners can hear them, the It Gets Better project helps to erode the separation and detachment that often accompanies mediatized depictions of suffering (Boltanski 1999) and helps to project a world in which the gay teenager, the bully, the teacher, the parent, the school administrator and the politician can find common narratives around which to congregate.

\section{Acknowledgement}

An earlier version of this paper was presented at the Annual Meeting of the American Anthropological Association, November 20-24, 2013, Chicago 


\section{References}

Alexander, B., \& Levine, A. (2008). Web 2.0 storytelling: Emergence of a new genre. Educause Review 43: 40-48.

Bakhtin, Mikhail M. (1981). The dialogic imagination: Four essays (trans. C. Emerson). Austin: University of Texas Press.

Bakhtin, Mikhail M. (1986). Speech genres and other late essays (trans. V.W. McGee). Austin: University of Texas Press.

Bamberg, Michael (1997) Positioning between structure and performance. Journal of Narrative and Life History7: 335-342.

Bamberg, Michael (2007). Introductory remarks. In Michael Bamberg (ed.) Narrative: State of the art, 1-5. Amsterdam: John Benjamins.

Bauman, Richard (1986). Story, performance, and event: Contextual studies of oral narrative. Cambridge: Cambridge University Press.

Bell, A. (1984). Language style as audience design. Langauge in Society 13: 145-204. 
Bhatia, V. K. (1993). Analysing genre: Language use in professional settings.

London: Longman.

Boltanski, Luc (1999). Distant suffering: morality, media and politics. Cambridge:

Cambridge University Press.

boyd, danah. (2014). It's complicated: The social lives of networked teens. New Haven: Yale University Press.

Brabham, Daren C. (2010). The potential of vernacular video for queer youth. Flow 13. Accessed July 12, 2013 from http://flowtv.org/2010/10/vernacular-video-forqueer-youth/

Briggs, Charles L., \& Bauman, Richard (1992). Genre, Intertextuality, and Social Power. Journal of Linguistic Anthropology2: 131-172. doi:10.1525/jlin.1992.2.2.131

Burgess, Jean (2006) Hearing ordinary voices: Cultural studies, vernacular creativity and digital storytelling. Continuum: Journal of Media \& Cultural Studies 20: 201-214

Cohler, Bertram J., \& Hammack, Phillip L. (2006). Making a gay identity: Life story and the construction of a coherent self. In Dan P. McAdams, Ruthella Josselson, \& Amia Lieblich (eds.), Identity and story: Creating self in narrative, 151-172.

Washington, DC: American Psychological Association.

Copeland, Charlton C. (2012). Creation storiesL Stanley Hauerwas, same-sex 
marriage, and narrative in law and theology. Law and Contemporary Problems 75: $86-113$

Derrida, Jacques (1980). The law of genre. Critical Inquiry 7: 55-81.

Dingwall, Robert (1977). 'Atrocity stories' and professional relationships. Work and Occupations 4: 371-396.

Dubrow, Heather (1982). Genre. London \& New York: Methuen \& Co.

Eggins, Susan and Slade, Diana (2005). Analysing casual conversation. London: Equinox Publishing.

Fagerjord, Anders (2003). Rhetorical convergence: Studying web media. In G. Liestøl, A. Morrison, \& T. Rasmussen (eds.), Digital media revisited, 293-325. Cambridge, MA, MIT Press.

Femmephane (2010, June 21). Why I don't like Dan Savage's “'It Gets Better”, project as a response to bullying. Retrieved on July 14, 2014 from http://tempcontretemps.wordpress.com/2010/09/30/why-i-dont-like-dan-savages-itgets-better-project-as-a-response-to-bullying/

Fivush, Robyn (2004). Voice and silence: A feminist model of autobiographical memory. In Joan M. Lucariello, Judith A. Hudson, Robyn Fivush, \& Patricia J. Bauer (eds.), The development of the mediated mind: Sociocultural context and cognitive 
development, 79-99. Mahwah, NJ: Erlbaum Associates Publishers.

Foucault, Michel (1990). The history of sexuality, Vol. 1: An introduction. New York: Vintage.

Fung, Heidi (1999) Becoming a moral child: The socialization of shame among young Chinese children. Ethos 27: 180-209.

Frobenius, M. (2014). Audience design in monologues: How vloggers involve their viewers. Journal of Pragmatics. doi:10.1016/j.pragma.2014.02.008

Genette, Gérard (1992). The architext: An introduction. (J. E. Lewin, Trans.). Berkeley: University of California Press.

Goffman, Erving (1974). Frame analysis: An essay on the organization of experience. New York: Harper and Row.

Goffman, Erving (1981). Forms of talk. Oxford: Blackwell.

Goltz, Dustin B. (2013). It Gets Better: Queer futures, critical frustrations, and radical potentials. Critical Studies in Media Communication 30: 135-151.

doi:10.1080/15295036.2012.701012

Günther, Suzanne (2005). Narrative reconstruction of past experiences: Adjustments and modifications in the process of recontextualizing a past experience. In 
Uta M. Quasthoff and Tabea Becker (eds.), Narrative Interaction, 285-301.

Amsterdam: Benjamins.

Hanks, William F. (1987). Discourse genres in a theory of practice. American

Ethnologist 14: 668-692. doi:10.1525/ae.1987.14.4.02a00050

Hanks, William F. (1989). Text and textuality. Annual Review of Anthropology 18:

95-127. doi:10.1146/annurev.an.18.100189.000523

Jauss, Hans R. (1974). Toward an aesthetics of reception (trans. T. Bahti). Brighton: Harvester Press.

Johnstone, Barbara (1990). Stories, community, and place: Narratives from middle America. Bloomington: Indiana University Press.

Jones, R. H. (2007). Imagined comrades and imaginary protections: Identity, community and sexual risk among men who have sex with men in China. Journal of Homosexuality 53: 83-115. doi:10.1300/J082v53n03_06

Kapchan, D. (1996). Gender on the market: Moroccan women and the revoicing of tradition. Philadelphia: University of Pennsylvania Press.

Kraus, Wolfgang (2007) The narrative negotiation of identity and belonging. . In Michael Bamberg (ed.), Narrative: State of the art, 123-132. Amsterdam: John Benjamins. 
Labov, William (1972). Language in the inner city. University Park: University of Pennsylvania Press.

Labov, William \& Waletzky, Joshua (1967). Narrative analysis: Oral versions of personal experience. In Essays on the verbal and visual arts. Proceedings of the 1966 Annual Spring Meeting of the American Ethnological Society (pp. 12-44). Seattle: University of Washington Press.

Lin, Timothy E. (1999). Social norms and judicial decisionmaking: Examining the role of narratives in same-sex adoption cases. Columbia Law Review 99: 739-794.

Lindgren, Simon (2012). Collective Coping through Networked Narratives: YouTube Responses to the Virginia Tech Shooting. Studies in Media and Communications7: 279-298. doi:10.1108/S2050-2060(2012)0000007017

Longacre, Robert E. (1968) Discourse, paragraph and sentence structure in selected Philippine languages. Dallas: Summer Institute of Linguistics.

Liang, A. C. (1997). The creation of coherence in coming-out stories. In A. Livia and K. Hall (eds.) Queerly phrased: language, gender, and sexuality (pp. 287-309) Oxford: Oxford University Press..

Lyons, John D. (2006) Exemplum. In Thomas O. Sloane (ed.) Encyclopedia of rhetoric. Oxford: Oxford University Press. 
Lyotard, Jean-François (1979) The postmodern condition. Manchester: Manchester University Press.

Martin, James R. \& Guenter Plum (1997). Construing experience: some story genres. In M. Bamberg (ed.) Oral versions of personal experience: three decades of narrative analysis. Special issue of Journal of Narrative and Life History, 7(1-4): 299-308.

McLean, Kate C. (2008). The emergence of narrative identity. Social and Personality Psychology Compass, 2(4), 1685-1702. doi:10.1111/j.1751-9004.2008.00124.x

McLagan, Meg (2006). Introduction: Making human rights claims public. American Anthropologist108: 191-195. doi:10.1525/aa.2006.108.1.191

Michaels, Sarah (1991). The dismantling of narrative. In Allyssa McCabe \& Carole Peterson (eds.), Developing narrative structure, 303-351. Hillsdale, NJ: Erlbaum.

Mills, C. Wright (1959). The sociological imagination. New York: Oxford University Press.

Mumby, Dennis K. (1987). The political function of narrative in organizations.

Communication Monographs 54:113-127.

Page, Ruth (2010). Re-examining narrativity: small stories in status updates. Text \& Talk30:423-444. doi:10.1515/text.2010.021 
Peterson, Eric E., \& Langellier, Kristin M. (2007). The performance turn in narrative studies. In Michael Bamberg (ed.) Narrative: State of the art, 205-214. Amsterdam: John Benjamins.

Polanyi, Livia (1985). Telling the American story: A structural and cultural analysis of conversational storytelling. Norwood, NJ: Ablex.

Plummer, Ken (1995). Telling sexual stories: Power, change and social worlds. London; New York: Routledge.

Propp, Vladimir (1968). Morphology of the folktale. Austin: University of Texas Press.

Rousseau, Jean-Jacques (1992). Confessions. New York: Knopf.

Rumelhart, D. E. (1975). Notes on a schema for stories. In D. G. Bobrow \& A. Collins (eds.), Representation and understanding: Studies in Cognitive Science, 185210. New York: Academic Press.

Savage, Dan \& Miller, Terry (2011). It gets better: Coming out, overcoming bullying, and creating a life worth living. New York: Penguin.

Schely-Newman, Esther (1999). 'I hear from people who read Torah... ': Reported speech, genres and gender Relations in personal narrative. Narrative Inquiry 9: 4968. doi:10.1075/ni.9.1.04sch 
Schiffrin, Deborah (1997). The transformation of experience, identity and context. In John Baugh, Crawford Feagin, Gregory Guy, and Deborah Schiffrin (eds.). Toward a social science of language, 41-55. Philadelphia: John Benjamins.

Shuman, Amy (1986). Storytelling rights: The uses of oral and written texts by urban adolescents. Cambridge: Cambridge University Press.

Shuman, Amy (1993). Gender and genre. In Susan T. Hollis, Linda Pershing, and M. Jane Young (eds.), Feminist theory and the study of folklore, 71-78. Chicago: University of Illinois Press.

Shuman, Amy (2007). Entitlement and empathy in personal narrative. In Michael Bamberg (ed.) Narrative: State of the art, 175-184. Amsterdam: John Benjamins.

Tannen, D. (1993). What's in a frame? Surface evidence for underlying expectations. In D. Tannen (ed.), Framing in discourse, 14-56. New York: Oxford University Press.

Toolan, Michael J. (1988). Narrative: A critical linguistic introduction. Routledge.

Tseng, Jason (2010, October 3). Does it really get better? A conscientious critique. The Bikerco Project. Accessed on July 14, 2014 at http://www.bilerico.com/2010/10/does_it_really_get_better.php 
Van Langenhove, Luc \& Harré, Rom. (1999). Introducing positioning theory. In R. Harré \& L. Van Langenhove (eds.), Positioning theory: Moral contexts of intentional action, 14-30. Oxford: Blackwell.

Walters, Suzanna D. (2014). The Tolerance trap: How God, genes, and good intentions are sabotaging gay equality. New York: NYU Press.

Wortham, Stanton (2000) Interactional positioning and narrative self-construction. Narrative Inquiry 10:157-184. 